\title{
ARTIKKELIT
}

\section{Aistivaikeudet, arki ja toimintakyky 90 vuotta täyttäneillä}

\author{
Linda Enroth ${ }^{1}$ ja Jutta Pulkki ${ }^{1}$ \\ ${ }^{1} Y$ bteiskuntatieteiden tiedekunta (terveystieteet) ja \\ Gerontologian tutkimuskeskus, Tampereen yliopisto
}

\begin{abstract}
Näkö- ja kuulovaikeudet ovat yhteydessä heikentyneeseen toimintakykyyn, mutta vanhoista vanhimmilla tätä yhteyttä ei ole juuri tutkittu. Tässä monimenetelmätutkimuksessa tarkastellaan 1) näkö- ja kuulovaikeuksien sekä molempien aistivaikeuksien yleisyyttä 90 vuotta täyttäneillä, 2) aistivaikeuksien yhteyttä liikkumiskykyyn ja itsearvioituun toimintakykyyn sekä 3) 90 vuotta täyttäneiden kokemuksia aistivaikeuksien merkityksestä arjessaan. Tutkimusaineisto koostui vuoden 2018 Tervaskannot 90+ -kyselytutkimuksen määrällisestä $(\mathrm{N}=1878)$ ja laadullisesta $(\mathrm{N}=63)$ aineistosta. Aistivaikeuksien yhteyttä liikkumiskykyyn ja itsearvioituun toimintakykyyn analysoitiin multinomiaalisella regressioanalyysilla. Laadullinen aineisto analysoitiin sisällönanalyysilla. Näkövaikeuksia raportoi 20 prosenttia, kuulovaikeuksia 15 prosenttia ja vaikeuksia molemmissa aisteissa 12 prosenttia tutkittavista. Aistivaikeuksia kokevilla oli heikompi liikkumiskyky, ja he arvioivat toimintakykynsä heikommaksi kuin he, joilla ei ollut aistivaikeuksia. Tutkittavien kokemukset aistivaikeuksista kiteytyivät hankaluuksiin yhteydenpidossa, mielekkäässä tekemisessä, päivittäisissä toiminnoissa ja liikkumisessa. Aistivaikeuksien kanssa arki kuvattiin myös sujuvaksi, esimerkiksi kompensaatiokeinojen ansiosta. Aistivaikeudet ovat yleisiä yli 90-vuotiailla ja hankaloittavat arjen toimintoja. Apuvälineillä voidaan tukea kommunikaatiota ja kotona asumista ja siten vaikuttaa elämänlaatuun erityisesti, jos molemmat aistit ovat heikentyneet.
\end{abstract}

\section{Johdanto}

Näkö- ja kuulovaikeuksien yhteys heikentyneeseen kykyyn selviytyä päivittäisistä toiminnoista ja liikkumisesta on osoitettu useissa tutkimuksissa. Erityisesti näkö- ja kuulovaikeudet yhdessä muodostavat riskin toimintakyvyn rajoitteille ja vaikeuttavat arjen toiminnoista selviytymistä. (Crews \& Campbell 2004; Brennan ym. 2005; Cimarolli \& Jopp 2014; Whitson ym. 2015; Davidson \& Guthrie 2017.) Näköja kuulovaikeudet vaikuttavat sosiaalisiin tilanteisiin ja kommunikointiin niin kotona kuin palvelutaloissa asuvilla (Cook ym. 2006; Yamada ym. 2015; Davidson \& Guthrie 2017; Roets-Merken ym. 2017). Aistivaikeudet lisäävät palvelujen käyttöä (Genther ym. 2013) ja terveydenhuollon kustannuksia (Javitt ym. 
2007). Näkö- ja kuulovaikeudet ovat muun muassa yhteydessä kaatumisriskiin (Kulmala ym. 2008; Lopez ym. 2011), mikä lisää tapaturmia ja terveyspalvelujen käyttöä (Kulmala ym. 2008). Vaikka tutkimustietoa aistivaikeuksien ja toimintakyvyn yhteydestä sekä merkityksestä arjen tilanteissa on runsaasti, hyvin vanhojen (85+ -vuotiaiden) osalta tietoa on vasta vähän ja näkö- ja kuuloaistin heikkenemisen yhteisvaikutuksesta ei juuri lainkaan.

Näkö- ja kuulovaikeudet lisääntyvät iän myötä ja erityisesti niiden samanaikainen esiintyminen yleistyy (Schneider ym. 2012; Dawes ym. 2014). Arviot näkö- ja kuulovaikeuksien yleisyydestä vaihtelevat kirjallisuudessa muun muassa erilaisten arviointimenetelmien vuoksi. Newcastle 85+ -tutkimuksessa tieto aistivaikeuksista kerättiin potilastietojärjestelmästä lähes tuhannelle yli 85-vuotiaalle. Kuulovaikeuksia todettiin noin 60 prosentilla ja näkövaikeuksia 37 prosentilla (Collerton ym. 2009). Leiden 85+ -tutkimuksessa aistivaikeuksia tarkasteltiin objektiivisten mittausten perusteella, jolloin kuulovaikeuksia havaittiin 85 prosentilla ja näkövaikeuksia 59 prosentilla. Vakavien kuulo- ja näkövaikeuksien (15 \% ja $21 \%$ ) osuudet olivat huomattavasti pienemmät. (Gussekloo ym. 2005.) Australialaistutkimuksen mukaan sekä näkö- että kuulovaikeuksia oli noin joka neljännellä 80-99-vuotiaista (Schneider ym. 2012), ja yhdysvaltalaistutkimuksessa, jossa tarkasteltiin noin 100-vuotiaita, 17 prosenttia raportoi näkövaikeuksia, 18 prosenttia kuulovaikeuksia ja 38 prosenttia vaikeuksia molemmissa aisteissa (Cimarolli \& Jopp 2014).

Vahvasti korkeaan ikään yhteydessä oleva ja yleisin näkökykyä heikentävä sairaus on kaihi, joka suomalaistutkimuksessa todettiin kahdella kolmesta yli 85-vuotiaasta. Muita näköaistiin vaikuttavia silmäsairauksia iäkkäillä ovat silmänpohjan ikärappeuma (28 \%) ja glaukooma (20\%). (Laitinen ym. 2010.) Diabeteksesta johtuva retinopatia on joka kolmannen näkövammaisuuden syy yli 65-vuotiailla (Käypä hoito 2017). Ikähuonokuuloisuus on yleisin etenevä ja palautumaton kuulovaikeus aikuisväestössä. Kuulovaikeuksien alkamisajankohtaan ja vakavuuteen vaikuttavat niin geneettinen alttius kuin ympäristötekijätkin, mutta tärkein riskitekijä on korkea ikä. (Graydon ym. 2019.) Toinen tärkeä tekijä on työperäinen melualtistus, minkä vuoksi ikähuonokuuloisuuden ilmaantuvuuteen usein yhdistetään miessukupuoli, lyhyempi koulutus ja pitkä työsuhde tuotantoteollisuudessa tai maanviljelyssä (Cruickshanks ym. 2010). Näkö- ja kuuloaistit heikkenevät usein asteittain, ja ne saatetaan kokea osaksi normaalia vanhenemista. Itseraportoitujen aistivaikeuksien pienempi osuus suhteessa objektiivisesti mitattuihin aistivaikeuksiin voi näin ollen viitata siihen, että aistin heikkenemiseen on vuosien varrella totuttu ja että käytössä on aistivaikeuksia kompensoivia apuvälineitä ja toimintatapoja.

Väestön vanheneminen on maailmanlaajuinen ilmiö, ja kehittyneissä maissa erityisesti vanhimpien ikäluokkien kasvu on ollut nopeaa. Vanhimpien ikäluokkien kasvun ennustetaan jatkuvan, ja Suomessa Tilastokeskuksen vuoden 2019 väestöennusteen mukaan 75 vuotta täyttäneiden määrä lähes kaksinkertaistuu nykyisestä puolesta miljoonasta ja 90 vuotta täyttäneiden määrä lähes kolminkertaistuu nykyisestä 54000:sta vuoteen 2040 mennessä (Suomen virallinen tilasto 2020). Korkea ikä on yhteydessä sekä aisti- että toimintakykyvaikeuksien yleistymiseen. Tässä monimenetelmätutkimuksessa tarkastellaan aistivaikeuksien (näkö ja kuulo) yhteyttä toimintakykyyn sekä niiden merkitystä arjen tilanteissa 90 vuotta täyttäneillä tamperelaisilla. Tervaskannot $90+$-tutkimuksen määrällisen ja laadullisen aineiston avulla vastataan kysymyksiin: 1) kuinka yleisiä näkö- ja kuulovaikeudet sekä vaikeudet molemmissa aisteissa ovat 90 vuotta täyttäneillä, 2) ovatko näkö- ja kuulovaikeudet ja vaikeudet molemmissa aisteissa yhteydessä itsearvioituun toimintakykyyn ja liikkumiskykyyn, ja 3) miten 90 vuotta täyttäneet kuvaavat erilaisten aistivaikeuksien merkitystä arjessaan. 


\section{Menetelmät}

\section{Monimenetelmätutkimus}

Tutkimuskysymyksiin vastattiin vuoden 2018 Tervaskannot 90+-kyselytutkimuksen laadullisella ja määrällisellä aineistolla. Tutkimustapaa, jolla tässä tutkimuksessa yhdistettiin erilaiset tutkimusotteet, voi kutsua konvergentiksi monimenetelmätutkimukseksi (mixed methods) (Sandelowski 2000; Creswell \& Plano Clark 2018, 68-77). Aineistot kerättiin samanaikaisesti kyselylomakkeella, jossa oli sekä valmiita vastausvaihtoehtoja sisältäviä kysymyksiä että avokysymys, johon vastaajat saivat kirjoittaa omia kommenttejaan. Määrällinen aineisto analysoitiin regressioanalyysilla ja laadullinen aineisto sisällönanalyysilla. Analyyseja tehtiin rinnakkain, ja niitä käytettiin toistensa tukena: laadullista aineistoa hyödynnettiin määrällisen aineiston muuttujien valinnassa ja määrällisen aineiston alustavia havaintoja hyödynnettiin laadullisen analyysin luokitteluissa. Saatuja tutkimustuloksia tarkastellaan pohdinnassa yhdessä. (Creswell \& Plano Clark 2018, 73, 76.) Monimenetelmätutkimuksen keinoin saamme laaja-alaisemman ymmärryksen aistitoimintojen yhteydestä toimintakykyyn ja niiden merkityksestä 90-vuotiaiden arjessa kuin asioita erikseen tarkasteltaessa (Zhang \& Creswell 2013).

\section{Aineisto}

Monitieteinen Tervaskannot 90+ -tutkimushanke aloitettiin vuonna 1995 (Jylhä ym. 2013). Vuodesta 2001 lähtien postikyselyaineistoa on kerätty kuusi kertaa (vuosina 2001, 2003,2007, 2010,2014 ja 2018) kaikilta sekä kotona asuvilta että ympärivuorokautisessa hoidossa olevilta 90-vuotiailta ja sitä vanhemmilta tamperelaisilta. Pienemmälle osajoukolle on tehty myös toimintakykymittauksia, biologisia määrityksiä varten on otettu verinäytteitä ja laadullista aineistoa on kerätty elämäkertahaastatteluilla. Tässä tutkimuksessa käytettiin Tervaskannot
90+ -hankkeen uusinta kyselyaineistoa vuodelta 2018. Kyselyyn vastasi 1878 henkilöä, ja vastausprosentti oli 76,7.

Aineistosta analysoitiin strukturoitujen monivalintakysymysten lisäksi kyselyn lopussa olevia avovastauksia. Avovastauksiin oli lomakkeessa ohje: "Tälle sivulle voitte halutessanne kirjoittaa lisätietoja." Avovastauksia kirjoitti 663 tutkittavaa, mikä oli $35 \%$ kaikista vastaajista. Kirjoitukset vaihtelivat lyhyistä muutaman rivin kommenteista muutaman sivun mittaisiin kuvauksiin vastaajan elämäntilanteesta. Vaikka mitään erityistä ei kysytty, monet kirjoitukset liittyivät kyselyssä kysyttyihin teemoihin, kuten terveyteen, palveluihin, läheisiin ja asumiseen. Vastaukset kirjoitettiin puhtaaksi ja tallennettiin Excel-tiedostoon.

Useimmat tutkittavat vastasivat kyselyyn itsenäisesti $(65,3 \%)$ tai saivat apua läheisiltä tai hoitohenkilökunnalta $(19,3 \%)$ lomakkeen täyttämisessä. Osalle tutkittavista kyselyyn vastasi sijaisvastaaja $(15,4 \%)$ esimerkiksi pitkälle edenneen muistisairauden vuoksi. Sijaisvastaajien käyttö on yleistä ja tarpeellista kattavan aineiston saamiseksi erityisesti silloin, kun tutkitaan väestön vanhimpia ikäryhmiä.

\section{Määrällinen aineisto}

\section{Selittävä muuttuja}

Aistitoimintoja kartoitettiin kahdella kysymyksellä, joista ensimmäinen oli:"Näettekö lukea sanomalehtitekstiä (silmälaseilla, jos niitä käytätte)?” Toinen kysymys koski kuuloaistia: "Kuuletteko toisen henkilön puheen, jos olette hänen kanssaan kahden (kuulolaitteen avulla, jos käytätte sitä)?" Vastausvaihtoehdot molempiin kysymyksiin olivat"kyllä","osittain"ja "en". Vaihtoehdot "osittain" ja "en" yhdistettiin luokaksi "vaikeuksia". Tämän jälkeen muodostettiin analyyseja varten neliluokkainen muuttuja: (1) ei vaikeuksia kummassakaan, (2) vaikeuksia kuulossa, (3) vaikeuksia näössä, ja (4) vaikeuksia molemmissa. 


\section{Selitettävät muuttujat}

Toimintakykyä tarkasteltiin itsearvioitua toimintakykyä ja liikkumiskykyä kuvaavien muuttujien avulla. Liikkumiskykyä kartoitettiin kolmella kysymyksellä: kykeneekö vastaaja liikkumaan sisällä, kävelemään ainakin 400 metriä ja kulkemaan portaita. Neljästä vastausvaihtoehdosta muodostettiin kaksi luokkaa: vaihtoehdot "kyllä, vaikeuksitta" ja "kyllä, mutta se on vaikeaa" yhdistettiin luokaksi "kyllä", ja vaihtoehdot "vain jos joku auttaa" sekä "en kykene" yhdistettiin luokaksi "ei”. Tämän jälkeen vastauksista muodostettiin yksi liikkumiskykyä kuvaava kolmiluokkainen muuttuja: (1) täysin itsenäinen (kykenee kolmeen toimintoon itsenäisesti), (2) osin itsenäinen (kykenee yhteen tai kahteen toimintoon itsenäisesti), tai (3) täysin avustettava (ei kykene yhteenkään toimintoon itsenäisesti).

Itsearvoitua toimintakykyä kartoitettiin kysymällä: "Millaiseksi itse arvioitte nykyisen toimintakykynne?" Vastausvaihtoehdot "erittäin hyvä" ja "melko hyvä” yhdistettiin luokaksi (1) hyvä, ja "melko huono" ja "huono" luokaksi (3) huono. Vastausvaihtoehto (2) "keskiverto" jäi omaksi luokakseen. Tämän kysymyksen kohdalla oli ohjeistettu, että jos lomakkeen täyttää sijaisvastaaja, kohta jätetään täyttämättä. Tutkittavista 163 (8,7 \%) ei vastannut kysymykseen, mistä 104 selittyy sillä, että kyselyyn vastaaja oli sijaisvastaaja. Kysymykseen vastasi 1715 henkilöä, joista 134 vastausta oli antanut joku muu tutkittavan puolesta. Kaikkia näitä vastauksia hyödynnettiin tässä tutkimuksessa.

\section{Vakioivat muuttujat}

Analyyseissa vakioitiin ikä ja sukupuoli sekä muistisairaus, diabetes, masennus, huimaus ja koulutusaste, sillä ne on tutkimuksissa yhdistetty sekä aistitoimintoihin (Crews \& Campbell 2004; Cruickshanks ym. 2010; Schneider ym. 2012; Armstrong ym. 2016; Davidson \& Guthrie 2017; Maharani ym. 2020) että toimintakykyyn (Aggarwal ym. 2000; Moreira ym.
2016; Halonen ym. 2017; Enroth ym. 2019). Sairauksia kartoitettiin kysymyksellä: "Onko lääkäri todennut teillä seuraavia sairauksia?", joista tässä tutkimuksessa keskityttiin muistisairauksiin ("dementia, Alzheimerin tauti tai muistin heikkeneminen"), diabetekseen ("sokeritauti, diabetes") ja masennukseen ("masentuneisuus, masennus"). Vastausvaihtoehdot olivat "kyllä" ja "ei". Huimausta selvitettiin kysymyksellä: "Huimaako teitä tai tunnetteko tasapainonne huonoksi?", ja vastausvaihtoina olivat "kyllä, usein", "kyllä, toisinaan" ja "ei koskaan". Koulutusasteesta muodostettiin kolmiluokkainen muuttuja yhdistämällä alkuperäisiä vastausvaihtoehtoja: (1) kansakoulu ("kansakoulu"), (2) keskiaste ("kansalaiskoulu tai keskikoulu","ammattikoulu tai ammatillinen koulutus", "kansanopisto tai kansankorkeakoulu") ja (3) korkea-aste ("lukio tai ylioppilas", "opistotason koulutus","akateeminen koulutus").

\section{Kuvailevat muuttujat}

Tutkittavien olinpaikka vastaushetkellä luokiteltiin kaksiluokkaiseksi siten, että vaihtoehdot "tavallinen asunto" ja "palveluasunto, jossa henkilökunta tavoitettavissa vain päivisin" luokiteltiin (1) kodiksi. Tehostetuksi palveluasumiseksi tai muuksi hoitopaikaksi (2) luokiteltiin vaihtoehdot"palveluasunto, jossa henkilökunta tavoitettavissa ympäri vuorokauden","vanhainkoti", "hoivakoti tai dementiakoti" sekä "terveyskeskus tai sairaala". Lomakkeessa kysyttiin myös: "Kuka kysymyksiin vastasi”, ja vastausvaihtoehdoista muodostettiin kaksi luokkaa: (1) vastasi itse tai joku auttoi vastaamisessa ja (2) joku toinen vastasi tutkittavan puolesta.

\section{Laadullinen aineisto}

Avovastauksista haettiin kuulo- ja näköaisteihin liittyviä mainintoja katkaistujen hakusanojen avulla. Hakusanat olivat kuul, pub*, $n \ddot{a} k^{*}$, silm$^{*}$, lauko* (tarkoittaen glaukoomaa), nää, näen*, aisti*. Tuloksena löytyi 97 kirjoitusta. Haku oli tarkoituksella laaja, jotta voi- 
tiin tunnistaa kaikki oleelliset aineisto-otteet. Laaja haku tarkoitti kuitenkin myös sitä, että mukaan tuli epätarkoituksenmukaisia otteita. Jatkoanalyysista poissuljettiin lopulta 34 kirjoitusta, sillä niissä ei käsitelty näkö- tai kuulovaikeuksia. Lopulliseen analysoitavaan aineistoon jäi 63 kirjoitusta.

\section{Tilastolliset analyysimenetelmät}

Aistitoiminnoissa havaittuja vaikeuksia kuvattiin frekvenssien ja prosenttiosuuksien avulla sukupuolittain. Vakioivien ja kuvailevien muuttujien yhteydet aistivaikeuksiin testattiin khiin neliö -testillä. Aistitoimintojen ja itsearvioidun toimintakyvyn sekä liikkumiskyvyn yhteyttä tarkasteltiin multinomiaalisella regressioanalyysilla, jossa vertailuryhminä olivat liikkumiskyvyltään täysin itsenäiset ja ne, jotka arvioivat toimintakykynsä hyväksi. Regressioanalyysissa naiset ja miehet yhdistettiin, koska aistivaikeuksien yhteys liikkumiskykyyn ja itsearvioituun toimintakykyyn oli samankaltainen molemmilla sukupuolilla ja suurempi tutkittavien määrä lisäsi tilastollista varmuutta. Monimuuttujamalleissa vakioitiin ensin 1) ikä ja sukupuoli, 2) malli1 + sairaudet ja huimaus, 3) malli1 + koulutus ja 4) lopuksi kaikki edellä mainitut samassa mallissa. Regressioanalyysin tuloksista esitetään suhteellinen riskisuhde (relative risk ratio $=\mathrm{RRR}$ ) ja $95 \%$ :n luottamusväli (LV). Tilastoanalyysit tehtiin IBM SPSS Statistics 25 -ohjelmalla.

\section{Aineistolähtöinen sisällönanalyysi}

Aistivaikeuksia koskevat avovastaukset $(63 \mathrm{kpl})$ analysoitiin aineistolähtöisen sisällönanalyysin avulla. Analyysi aloitettiin pelkistämällä, eli tiivistämällä avovastausten ydinsisältö niin, että saatiin vastaus tutkimuskysymykseen aistivaikeuksien merkityksestä arjessa. Kuudestakymmenestäkolmesta avovastauksesta 33 sisälsi vain maininnan aistivaikeudesta, esimerkiksi "näköni on huonontunut", mutta ei sitä, millainen merkitys aistivaikeudella on arjes- sa. Näistä avovastauksista ei muodostettu pelkistyksiä. Sitä vastoin 30 avovastauksesta osa sisälsi useampia merkityksiä, ja niistä tehtiin näin ollen useampia pelkistyksiä. Pelkistyksissä haluttiin säilyttää toisaalta vastausten informaatio ja toisaalta tiivistää aineistoa niin, että samansisältöiset vastaukset saivat samanlaisen pelkistyksen. Osa aineisto-otteista oli jo valmiiksi tiiviitä kuvauksia, kuten "huono näkö hankaloittaa elämää" tai "hankalinta on huono näkö”. Näistä ei ole mahdollista tiivistää informaatiota, ja jos näin tekisi, vaarana olisi ylitulkitseminen. Pelkistyksiä muodostettiin yhteensä 37. Samansisältöiset pelkistykset ryhmiteltiin edelleen 10 alaluokkaan sen mukaan, kuvattiinko aistivaikeuden merkitystä yleisesti vai spesifisti tietyllä elämän osa-alueella tai toiminnassa. Alaluokissa viittaukset näkö- ja kuulovaikeuksiin pidettiin vielä erillään. Alaluokat yhdistettiin viiteen yläluokkaan, jotka kuvaavat aistivaikeuksien merkitystä arjessa. Sisällönanalyysi pelkistyksistä yläluokkiin on kuvattu taulukossa 1.

\section{Tulokset}

Aistivaikeuksien ja toimintakyvyn yhteys

Tutkimukseen osallistui 1387 naista (73,9\%) ja 491 miestä (26,1 \%),joiden keski-ikä oli 92,7 vuotta ja joista noin 70 prosenttia asui kotona. Hieman alle puolella kaikista 1878 tutkimukseen osallistujasta oli näkö- tai kuulovaikeuksia. Sekä miehistä että naisista noin 15 prosentilla oli vaikeuksia kuulla toisen henkilön puhetta, ja näkövaikeuksia koki hieman useampi (miehistä $17 \%$ ja naisista $20 \%$ ). Vaikeuksia molemmissa aisteissa raportoi 13 prosenttia naisista ja 8 prosenttia miehistä. (Taulukko 2.)

Aistivaikeudet (näkö- tai kuulovaikeus vs. ei aistivaikeutta) olivat sekä miehillä että naisilla yleisempiä tehostetussa palveluasumisessa tai muussa hoitopaikassa olevilla ( $\mathrm{P}$-arvo $<0,001)$ ja heillä, joilla sijaisvastaaja vastasi kyselyyn ( $\mathrm{P}$-arvo $<0,001)$. Myös heillä, joilla oli 
Taulukko 1. Laadullinen sisällönanalyysi pelkistyksistä yläluokkiin.

\begin{tabular}{|c|c|c|}
\hline Pelkistys & Alaluokka & Yläluokka \\
\hline Huono kuulo iso ongelma & \multirow{4}{*}{$\begin{array}{l}\text { Huono kuulo tai näkökyky iso(in) } \\
\text { ongelma }\end{array}$} & \multirow{8}{*}{$\begin{array}{l}\text { Huono kuulo } \\
\text { ja/tai näkö } \\
\text { hankaloittaa } \\
\text { elämää } \\
\text { yleensä }\end{array}$} \\
\hline Suurin vaikeus huono näkö & & \\
\hline Näkökyvyn merkitys elämänlaadulle suuri & & \\
\hline Menisi hyvin, jos kuulisi ja näkisi paremmin & & \\
\hline Huono näkö aiheuttaa suuria vaikeuksia & \multirow{4}{*}{$\begin{array}{l}\text { Huono kuulo tai näkö hankaloittaa } \\
\text { elämää }\end{array}$} & \\
\hline Huono näkö rajoittaa elämää paljon & & \\
\hline $\begin{array}{l}\text { Toive paremmasta elämästä näkövamman } \\
\text { kanssa }\end{array}$ & & \\
\hline Huono kuulo hankaloittaa suuresti elämää & & \\
\hline Huono kuulo haittaa asiointia puhelimella & \multirow{3}{*}{$\begin{array}{l}\text { Huono kuulo tai näkö hankaloittaa } \\
\text { puhelimen käyttöä }\end{array}$} & \multirow{5}{*}{$\begin{array}{l}\text { Huono kuvlo } \\
\text { tai näkö } \\
\text { haittaa } \\
\text { yhteydenpitoa }\end{array}$} \\
\hline Puhelimen käyttö hankalaa & & \\
\hline Huono näkö haittaa puhelimen käyttöä & & \\
\hline Huono kuulo haittaa keskustelua & \multirow{2}{*}{$\begin{array}{l}\text { Huono kuulo hankaloittaa } \\
\text { sosiaalisia suhteita }\end{array}$} & \\
\hline $\begin{array}{l}\text { Kohdellaan dementikkona, vaikka vika } \\
\text { kuulossa }\end{array}$ & & \\
\hline Huono kuulo haittaa TV:n katselua & \multirow{3}{*}{$\begin{array}{l}\text { Huono kuulo hankaloittaa } \\
\text { mielekästä toimintaa }\end{array}$} & \multirow{9}{*}{$\begin{array}{l}\text { Huono kuulo } \\
\text { tai näkö } \\
\text { hankaloittaa } \\
\text { arjen } \\
\text { mielekästä } \\
\text { tekemistä }\end{array}$} \\
\hline $\begin{array}{l}\text { Huono kuulo estää osallistumasta } \\
\text { musiikkitapahtumiin }\end{array}$ & & \\
\hline Huono kuulo haittaa päivittäisiä keskusteluita & & \\
\hline Huono näkö haittaa lukemista & \multirow{6}{*}{$\begin{array}{l}\text { Huono näkö hankaloittaa } \\
\text { mielekästä toimintaa }\end{array}$} & \\
\hline Huono näkö haittaa TV:n katselua & & \\
\hline Huono näkö haittaa käsitöiden tekemistä & & \\
\hline Huono näkö estää tekemistä & & \\
\hline Huonon näön takia ei pääse matkalle & & \\
\hline Huono näkö vaikuttaa kirjoittamiseen & & \\
\hline Huono näkö haittaa bussilla kulkemista & \multirow{3}{*}{$\begin{array}{l}\text { Huono kuulo ja näkö hankaloittavat } \\
\text { liikkumista }\end{array}$} & \multirow{5}{*}{\begin{tabular}{|l|} 
Huono kuulo \\
ja/tai näkö \\
hankaloittaa \\
fyysistä \\
toimintakykyä
\end{tabular}} \\
\hline Huono näkö haittaa ulkona talvella liikkumista & & \\
\hline $\begin{array}{l}\text { Huono näkö ja kuulo haittaavat tasapainoa ja } \\
\text { kävelyä }\end{array}$ & & \\
\hline Huono näkö vaikuttaa toimintakykyyn & \multirow[t]{2}{*}{ Huono näkö haittaa toimintakykyä } & \\
\hline Näkö estää varpaankynsien leikkaamisen & & \\
\hline $\begin{array}{l}\text { Lukulaite, jonka avulla näkee kirjoittaa ja } \\
\text { lukea postit }\end{array}$ & \multirow[t]{4}{*}{$\begin{array}{l}\text { Kompensaatiokeinoja huonoon } \\
\text { näköön ja kuuloon }\end{array}$} & \multirow{10}{*}{$\begin{array}{l}\text { Huonon } \\
\text { kuulon tai } \\
\text { näkökyvyn } \\
\text { kanssa pärjääa }\end{array}$} \\
\hline Valaiseva suurennuslasi & & \\
\hline Suurentava kirkasvalolamppu & & \\
\hline Kuulolaite (digi), kuulee mm. TV:n & & \\
\hline Huono näkö ei haittaa kotona asumista & \multirow{6}{*}{$\begin{array}{l}\text { Huono näkökyky tai kuulo eivät } \\
\text { haittaa elämää }\end{array}$} & \\
\hline $\begin{array}{l}\text { Huono näkö ei haittaa kutomista ja kryptojen } \\
\text { tekoa }\end{array}$ & & \\
\hline Huono näkö ei haittaa lukemista & & \\
\hline Huono näkö ei haittaa kotona asumista & & \\
\hline $\begin{array}{l}\text { Huono näkö ei haittaa lukemista ja ristikoiden } \\
\text { tekemistä }\end{array}$ & & \\
\hline Parempi kuitenkin kuuro kuin sokea & & \\
\hline
\end{tabular}


usein huimausta ( $\mathrm{P}$-arvo $<0,001$ ), muistisairaus $(\mathrm{P}$-arvo $=0,001)$ tai masennusta $(\mathrm{P}$-arvo $<0,01)$ oli useammin aistivaikeuksia. Kansakoulun käyneillä naisilla aistivaikeudet olivat yleisem- piä kuin korkeammin koulutetuilla (P-arvo $<0,001)$, mutta miehillä koulutusasteiden väliset erot olivat pieniä.

Taulukko 2. Tervaskannot 9o+ -tutkimuksen vuoden 2018 aineiston kuvaus aistitoiminnoissa havaittujen vaikeuksien mukaan ja sukupuolittain.

\begin{tabular}{|c|c|c|c|c|}
\hline & $\begin{array}{c}\text { Ei } \\
\text { vaikeuksia }\end{array}$ & $\begin{array}{l}\text { Vaikeuksia } \\
\text { kuulossa }\end{array}$ & $\begin{array}{l}\text { Vaikeuksia } \\
\text { näössä }\end{array}$ & $\begin{array}{l}\text { Vaikeuksia } \\
\text { molemmissa }\end{array}$ \\
\hline & $\mathrm{n}(\%)$ & $\mathrm{n}(\%)$ & $\mathrm{n}(\%)$ & $\mathrm{n}(\%)$ \\
\hline Naiset & $714(52,4)$ & $201(14,8)$ & $275(20,2)$ & $172(12,6)$ \\
\hline \multicolumn{5}{|l|}{ Olinpaikka } \\
\hline Koti & $548(59,7)$ & $141(15,4)$ & $155(16,9)$ & $74(8,1)$ \\
\hline $\begin{array}{l}\text { Tehostettu palveluasuminen } \\
\text { tai muu hoitopaikka }\end{array}$ & $157(37,5)$ & $58(13,8)$ & $112(26,7)$ & $92(22,0)$ \\
\hline \multicolumn{5}{|l|}{ Kyselyyn vastaaja } \\
\hline Vastasi itse tai autettuna & $662(56,6)$ & $183(15,7)$ & $207(17,7)$ & $117(10,0)$ \\
\hline Joku muu vastasi puolesta & $51(26,7)$ & $18(9,4)$ & $67(35,1)$ & $55(28,8)$ \\
\hline \multicolumn{5}{|l|}{ Itsearvoitu toimintakyky } \\
\hline Hyvä & $205(74,8)$ & $34(12,4)$ & $23(8,4)$ & $12(4,4)$ \\
\hline Keskiverto & $281(61,0)$ & $86(14,8)$ & $80(17,4)$ & $32(6,9)$ \\
\hline Huono & $183(36,7)$ & $83(16,7)$ & $132(26,5)$ & $100(20,1)$ \\
\hline \multicolumn{5}{|l|}{ Liikkumiskyky } \\
\hline Täysin itsenäinen & $376(68,6)$ & $83(15,1)$ & $65(11,9)$ & $24(4,4)$ \\
\hline Osin itsenäinen & $254(43,9)$ & $102(17,6)$ & $136(23,5)$ & $87(15,0)$ \\
\hline Täysin avustettava & $50(25,5)$ & $14(7,1)$ & $74(37,8)$ & $58(29,6)$ \\
\hline \multicolumn{5}{|l|}{ Huimaus } \\
\hline Ei koskaan & $162(67,8)$ & $28(11,7)$ & $30(12,6)$ & $19(7,9)$ \\
\hline Kyllä, toisinaan & $371(55,4)$ & $105(15,7)$ & $125(18,7)$ & $69(10,3)$ \\
\hline Kyllä, usein & $171(41,3)$ & $62(15,0)$ & $107(25,8)$ & $74(17,9)$ \\
\hline \multicolumn{5}{|l|}{ Muistisairaus } \\
\hline $\mathrm{Ei}$ & $478(60,3)$ & $112(14,1)$ & $132(16,6)$ & $71(9,0)$ \\
\hline Kyllä & $226(40,8)$ & $86(15,5)$ & $141(25,5)$ & $101(18,2)$ \\
\hline \multicolumn{5}{|l|}{ Masennus } \\
\hline $\mathrm{Ei}$ & $616(55,6)$ & $156(14,1)$ & $210(19,0)$ & $126(11,4)$ \\
\hline Kyllä & $88(36,8)$ & $42(17,6)$ & $63(26,4)$ & $46(19,2)$ \\
\hline \multicolumn{5}{|l|}{ Diabetes } \\
\hline $\mathrm{Ei}$ & $582(52,8)$ & $156(14,1)$ & $229(20,8)$ & $136(12,3)$ \\
\hline Kyllä & $122(50,0)$ & $42(17,2)$ & $44(18,0)$ & $36(14,8)$ \\
\hline \multicolumn{5}{|l|}{ Koulutusaste } \\
\hline Korkea-asteen koulutus & $141(62,9)$ & $23(10,3)$ & $34(15,2)$ & $26(11,6)$ \\
\hline Keskiasteen koulutus & $230(54,1)$ & $74(17,4)$ & $82(19,3)$ & $39(9,2)$ \\
\hline Kansakoulu & $339(48,3)$ & $103(14,7)$ & $153(21,8)$ & $107(15,2)$ \\
\hline
\end{tabular}




\begin{tabular}{|c|c|c|c|c|}
\hline & $\begin{array}{c}\text { Ei } \\
\text { vaikeuksia }\end{array}$ & $\begin{array}{l}\text { Vaikeuksia } \\
\text { kuulossa }\end{array}$ & $\begin{array}{c}\text { Vaikeuksia } \\
\text { näössä }\end{array}$ & $\begin{array}{c}\text { Vaikeuksia } \\
\text { molemmissa }\end{array}$ \\
\hline Miehet & $290(59,8)$ & $75(15,5)$ & $80(16,5)$ & $40(8,2)$ \\
\hline \multicolumn{5}{|l|}{ Olinpaikka } \\
\hline Koti & $246(66,5)$ & $55(14,9)$ & $49(13,2)$ & $20(5,4)$ \\
\hline $\begin{array}{l}\text { Tehostettu palveluasuminen } \\
\text { tai muu hoitopaikka }\end{array}$ & $42(38,5)$ & $20(18,3)$ & $28(25,7)$ & $19(17,4)$ \\
\hline \multicolumn{5}{|l|}{ Kyselyyn vastaaja } \\
\hline Vastasi itse tai autettuna & $279(63,6)$ & $69(15,7)$ & $67(15,3)$ & $24(5,5)$ \\
\hline Joku muu vastasi puolesta & $10(22,7)$ & $6(13,6)$ & $13(29,5)$ & $15(34,1)$ \\
\hline \multicolumn{5}{|l|}{ Itsearvioitu toimintakyky } \\
\hline Hyvä & $121(78,1)$ & $19(12,3)$ & $14(9,0)$ & $1(0,6)$ \\
\hline Keskiverto & $90(59,6)$ & $28(18,5)$ & $24(15,9)$ & $9(6,0)$ \\
\hline Huono & $68(45,3)$ & $22(14,7)$ & $36(24,0)$ & $24(16,0)$ \\
\hline \multicolumn{5}{|l|}{ Liikkumiskyky } \\
\hline Täysin itsenäinen & $212(69,3)$ & $48(15,7)$ & $35(11,4)$ & $11(3,6)$ \\
\hline Osin itsenäinen & $70(48,6)$ & $22(15,3)$ & $32(22,2)$ & $20(13,9)$ \\
\hline Täysin avustettava & $4(13,8)$ & $5(17,2)$ & $12(41,4)$ & $8(27,6)$ \\
\hline \multicolumn{5}{|l|}{ Huimaus } \\
\hline Ei koskaan & $64(74,4)$ & $8(9,3)$ & $12(14,0)$ & $2(2,3)$ \\
\hline Kyllä, toisinaan & $174(60,8)$ & $47(16,4)$ & $44(15,4)$ & $21(7,3)$ \\
\hline Kyllä, usein & $49(45,8)$ & $18(16,8)$ & $24(22,4)$ & $16(15,0)$ \\
\hline \multicolumn{5}{|l|}{ Muistisairaus } \\
\hline $\mathrm{Ei}$ & $197(65,9)$ & $46(15,4)$ & $42(14,0)$ & $14(4,7)$ \\
\hline Kyllä & $92(50,3)$ & $29(15,8)$ & $37(20,2)$ & $25(13,7)$ \\
\hline \multicolumn{5}{|l|}{ Masennus } \\
\hline $\mathrm{Ei}$ & $260(62,5)$ & $60(14,4)$ & $68(16,3)$ & $28(6,7)$ \\
\hline Kyllä & $29(43,9)$ & $15(22,7)$ & $11(16,7)$ & $11(16,7)$ \\
\hline \multicolumn{5}{|l|}{ Diabetes } \\
\hline $\mathrm{Ei}$ & $239(62,1)$ & $61(15,8)$ & $57(14,8)$ & $28(7,3)$ \\
\hline Kyllä & $50(51,5)$ & $14(14,4)$ & $22(22,7)$ & $11(11,3)$ \\
\hline \multicolumn{5}{|l|}{ Koulutusaste } \\
\hline Korkea-asteen koulutus & $69(60,5)$ & $20(17,5)$ & $19(16,7)$ & $6(5,3)$ \\
\hline Keskiasteen koulutus & $95(61,7)$ & $29(18,8)$ & $21(13,6)$ & $9(5,8)$ \\
\hline Kansakoulu & $122(57,8)$ & $26(12,3)$ & $38(18,0)$ & $25(11,8)$ \\
\hline
\end{tabular}

Tehostettu palveluasuminen tai muu hoitopaikka: palveluasunto, jossa henkilökunta tavoitettavissa ympäri vuorokauden, vanhainkoti, hoivakoti, dementiakoti, terveyskeskus tai sairaala.

Liikkumiskyky: sisällä liikkuminen, 400 metrin kävely ja portaiden kulkeminen.

Aistivaikeudet olivat yhteydessä heikompaan liikkumiskykyyn ja itsearvioituun toimintakykyyn. Kuulovaikeuksia kokevilla oli suurempi riski heikompaan liikkumiskykyyn (osin itsenäinen RRR 1,66; 95 \% LV 1,25-2,21; täysin avustettava RRR 1,51; 95 \% LV 0,86$2,65)$ kuin heillä, joilla ei ollut aistivaikeuksia. Myös näkövaikeudet lisäsivät heikentyneen liikkumiskyvyn riskiä (osin itsenäinen RRR 2,90; $95 \%$ LV 2,17-3,87; täysin avustettava
RRR 8.75; 95 \% LV 5.81-13.17). Suurin riski heikentyneeseen liikkumiskykyyn oli heillä, joilla oli sekä näkö- että kuulovaikeuksia (osin itsenäinen RRR 5,12; 95 \% LV 3,39-7,73; täysin avustettava RRR 18.39; 95 \% LV 11.0830.51). Sairauksien ja huimauksen vakiointi heikensi aistivaikeuksien ja heikentyneen liikkumiskyvyn yhteyttä mutta ei kuitenkaan poistanut sitä. (Taulukko 3.) 
Kuulovaikeuksia kokevilla oli aistivaikeuksia kokemattomia suurempi riski keskivertoon (RRR 1,54; $95 \%$ LV 1,06-2,23) tai huonoon (RRR 2,47; 95 \% LV 1,70-3,59) itsearvioituun toimintakykyyn hyvän itsearvioidun toimintakyvyn sijaan. Myös näkövaikeudet lisäsivät riskiä keskivertoon (RRR 2,33; $95 \%$ LV 1,55-3,49) ja huonoon (RRR 5,50; $95 \%$ LV 3,70-8,16) itsearvioituun toimintakykyyn. Suurin riski heikentyneeseen itsearvioituun toimintakykyyn oli heillä, joilla oli sekä näköettä kuulovaikeus (keskiverto RRR 2,51; $95 \%$ LV 1,32-4,78; huono RRR 11,03; 95 \% LV 6,06-20,07). Sairauksien ja huimauksen vakioiminen heikensi aistivaikeuksien ja itsearvioidun toimintakyvyn yhteyttä, mutta yhtä poikkeusta lukuun ottamatta (hyvä ja keskiverto toimintakyky eivät eronneet kuulovaikeuksia raportoineilla) yhteydet pysyivät tilastollisesti merkitsevinä. (Taulukko 3.)

Taulukko 3. Multinomiaalinen regressioanalyysi aistitoimintojen yhteydestä liikkumiskykyyn ja itsearvioituun toimintakykyyn. Liikkumiskyvyssä vertailuryhmänä on täysin itsenäiset henkilöt ja itsearvioidussa toimintakyvyssä ne, jotka arvioivat toimintakykynsä hyväksi.

\begin{tabular}{|c|c|c|c|c|}
\hline & $\begin{array}{l}\text { Malli } 1 \\
\text { RRR (95\% LV) }\end{array}$ & $\begin{array}{l}\text { Malli } 2 \\
\text { RRR (95\% LV) }\end{array}$ & $\begin{array}{l}\text { Malli } 3 \\
\text { RRR (95\% LV) }\end{array}$ & $\begin{array}{l}\text { Malli } 4 \\
\text { RRR (95\% LV) }\end{array}$ \\
\hline $\begin{array}{l}\text { LIIKKUMISKYKY } \\
\text { Osin itsenäinen } \\
\text { Ei vaikeuksia (Ref.) }\end{array}$ & & & & \\
\hline Vaikeuksia kuulossa & $1,66(1,25-2,21)$ & $1,42(1,04-1,92)$ & $1,59(1,19-2,13)$ & $1,36(1,00-1,84)$ \\
\hline Vaikeuksia näössä & $2,90(2,17-3,87)$ & $2,37(1,75-3,21)$ & $2,83(2,11-3,78)$ & $2,32(1,71-3,16)$ \\
\hline $\begin{array}{l}\text { Vaikeuksia molemmissa } \\
\text { Ikä }\end{array}$ & $\begin{array}{l}5,12(3,39-7,73) \\
1,11(1,07-1,16)\end{array}$ & $\begin{array}{l}3,74(2,43-5,73) \\
1,10(1,06-1,15)\end{array}$ & $\begin{array}{l}5,05(3,34-7,64) \\
1,11(1,07-1,16)\end{array}$ & $\begin{array}{l}3,77(2,45-5,81) \\
1,10(1,06-1,15)\end{array}$ \\
\hline Sukupuoli (Ref. nainen) & $0,47(0,37-0,59)$ & $0,44(0,34-0,57)$ & $0,49(0,38-0,62)$ & $0,45(0,35-0,59)$ \\
\hline
\end{tabular}

\section{Täysin avustettava}

Ei vaikeuksia (Ref.)

Vaikeuksia kuulossa

Vaikeuksia näössä

Vaikeuksia molemmissa

Ikä

Sukupuoli (Ref. nainen)

$\begin{array}{llll}1,51(0,86-2,65) & 1,21(0,66-2,22) & 1,50(0,85-2,64) & 1,21(0,65-2,23) \\ 8,75(5,81-13,17) & 6,24(3,94-9,87) & 8,30(5,48-12,59) & 5,93(3,71-9,47) \\ 18,39(11,08-30,51) & 10,48(5,98-18,36) & 18,55(11,14-30,90) & 10,85(6,15-19,15) \\ 1,14(1,08-1,21) & 1,15(1,08-1,22) & 1,13(1,06-1,20) & 1,14(1,07-1,22) \\ 0,29(0,19-0,45) & 0,29(1,18-0,47) & 0,27(0,17-0,43) & 0,26(0,16-0,43)\end{array}$

\section{ITSEARVIOITU TOIMINTAKYKY}

\section{Keskiverto}

Ei vaikeuksia (Ref.)

Vaikeuksia kuulossa

Vaikeuksia näössä

Vaikeuksia molemmissa

Ikä

Sukupuoli (Ref. nainen)

$1,43(0.97-2,11)$
$2,12(1,39-3,23)$
$2,09(1,08-4,02)$
$1,08(1,03-1,14)$
$0,59(0,44-0,78)$

$1,50(1,04-2,18)$

$1,38(0,93-2,04)$

$2,33(1,54-3,52)$

$2,12(1,38-3,24)$

$2,13(1,10-4,12)$

$1,09(1,03-1,15)$

$1,10(1,05-1,16)$

$0,63(0,48-0,83)$

$0,61(0,45-0,81)$

$0,59(0,44-0,78)$

\section{Huono}

Ei vaikeuksia (Ref.)

Vaikeuksia kuulossa

Vaikeuksia näössä

Vaikeuksia molemmissa

Ikä

$0,61(0,46-0,80)$

$\begin{array}{llll}2,47(1,70-3,59) & 1,96(1,29-2,98) & 2,43(1,67-3,53) & 1,90(1,25-2,90) \\ 5,50(3,70-8,16) & 4,04(2,62-6,25) & 5,38(3,60-8,03) & 3,94(2,53-6,13) \\ 11,03(6,06-20,07) & 6,63(3,50-12,56) & 10,77(5,91-19,61) & 6,74(3,55-12,81) \\ 1,12(1,06-1,18) & 1,09(1,03-1,15) & 1,11(1,05-1,17) & 1,08(1,02-1,15) \\ 0,60(0,45-0,80) & 0,62(0,45-0,85) & 0,61(0,46-0,81) & 0,61(0,44-0,85)\end{array}$

$\mathrm{RRR}=$ relative risk ratio eli suhteellinen riskisuhde, $\mathrm{LV}=$ luottamusväli, Ref. = referenssi eli vertailuryhmä.

Liikkumiskyky: sisällä liikkuminen, 400 metrin kävely ja portaiden kulkeminen.

Malli 1 = ikä ja sukupuoli; Malli 2 = Malli 1 + muistisairaus, diabetes, masennus ja huimaus; Malli 3 = Malli 1 + koulutus, Malli 4 = ikä, sukupuoli, muistisairaus, diabetes, masennus, huimaus ja koulutus. 
Aistivaikeudet ja kokemus arjesta

Muuten menee iban byvin, kun kuulisi ja näkisi paremmin.

Vastaajat kokivat buonon kuulon ja näön pääosin hankaloittavan elämää. Tarkemmin ottaen huono kuulo ja näkö haittasivat yhteydenpitoa ja hankaloittivat mielekästä tekemistä sekä fyysistä toimintakykyä vaativia tehtäviä. Vastauksissa oli myös mainintoja siitä, miten huonon kuulon ja näön kanssa on oppinut elämään ja että arki sujuu aistivaikeuksista huolimatta. (Taulukko 1.)

Vastauksissa kuvattiin erilaisia kommunikaatiovaikeuksia. Sekä huono kuulo että näkö haittasivat vastaajien mukaan päivittäisten asioiden hoitamista puhelimella. Lisäksi huonon kuulon koettiin vaikeuttavan sosiaalisten suhteiden ylläpitämistä, kun keskustelu muiden kanssa ei onnistu. Seuraava esimerkki kuvaa, kuinka sosiaaliset suhteet voivat vaikeutua keskustelun vaikeuden lisäksi senkin vuoksi, että huonosti kuulevaa henkilöä kohdellaan muistisairaana.

Minut kutsuttiin syömään ybteiseen tilaan ja voisin jutella järkevien ibmisten kanssa ja ettei "meteli" haittaisi kuuntelemista. Minua kohdellaan joskus kuin dementikkoa, vaikka vika on kuulossa. Se loukkaa kovasti.

Aistivaikeudet merkitsivät vastaajille aikaisemmin mielekkään tekemisen vaikeutumista tai siitä luopumista. Huonon kuulon koettiin hankaloittavan esimerkiksi television katselua ja musiikkitapahtumiin osallistumista. Huono näkö haittasi myös lukemista ja käsitöiden tekemistä.

Koska minulla on $70 \%$ näkövamma, aibeuttaa se suuria vaikeuksia, mm. lukeminen, pubelimen käyttö, bussilla kulkeminen, ostokset, ulkona talvessa liikkuminen on vaikeaa. Näkö- ja kuulovammat vaikuttavat myös tasapainoon, joten kävely on horjuvaa.
Kuten edellä oleva tekstiote kuvaa, buonon kuulon ja näön koettiin hankaloittavan myös fyysistä toimintakykyä. Erilaisten liikkumiseen liittyvien ongelmien lisäksi vastauksissa mainittiin myös, kuinka huono näkö esti varpaankynsien leikkaamisen.

Avovastauksissa ei kuvattu kuitenkaan vain huonon kuulon ja näön aiheuttamia haittoja. Osa vastaajista toi esiin sen, kuinka aistivaikeuksista huolimatta lukeminen, television katselu, teknologian käyttö, kutominen ja ristikoiden tekeminen oli edelleen mahdollista. Vastaajat olivat keksineet keinoja, miten huonoa kuuloa ja näköä saattoi kompensoida ja näin jatkaa muun muassa harrastuksiaan. Yksi vastaaja kertoi paitsi ottaneensa käyttöön kompensointikeinon urheilun seuraamiseen myös keskittyneensä niihin asioihin, joita huono kuulo ei hankaloita.

Hankalinta on buono kuulo. Seuraan tarkoin maailman menoa, luen Aamulebden jo lounaaseen mennessä. Uutiset kuulen jotenkin, mutta on ajankohtais- ja poliittisia objelmia, joista olisin erittäin kiinnostunut. Samoin seuraan urheiluohjelmia, vaikka en selostusta kuulekaan. Käytän kiertokonsteja esim. purun kuosia ja tunnen useimmat tunnetut urbeilijat, kun olen pitkään kisoja seurannut. ... Lukeminen on nykyään kantava voima. Kirjaston kotipalvelu tuo minulle 1015 kirjaa kuukaudessa. ... Teen myös kaikki ristikot mitä käsiini saan. Täällä olisi monenlaisia tilaisuuksia, mutta kuuloni rajoittaa, esim. musiikki on muuttunut erilaiseksi. Käyn kuitenkin sutikerhossa, vaikka ei minusta Rembranttia tulekaan. Parempi kuitenkin kuuro kuin sokea.

\section{Pohdinta}

Tässä monimenetelmätutkimuksessa tarkasteltiin Tervaskannot 90+ -aineiston avulla aistivaikeuksien (näkö ja kuulo) yhteyttä toiminta- 
kykyyn sekä niiden merkitystä arjessa 90 vuotta täyttäneillä tamperelaisilla. Tutkimus osoitti, että näkö- ja kuulovaikeudet ovat erikseen yhteydessä heikentyneeseen liikkumiskykyyn ja itsearvioituun toimintakykyyn ja että riski on erityisen suuri heillä, joilla on ongelmia molemmissa aisteissa. Tutkittavien omat kokemukset aistivaikeuksista kiteytyivät hankaluuksiin yhteydenpidossa, mielekkäässä tekemisessä, päivittäisissä toiminnoissa ja liikkumisessa. Vastauksissa oli kuvauksia myös siitä, että aistivaikeudet eivät haitanneet arkielämää tai niiden kanssa oli opittu elämään erilaisten kompensaatiokeinojen avulla. Aistivaikeuksien yhteys heikentyneeseen toimintakykyyn on osoitettu aikaisemmissakin tutkimuksissa, mutta ne ovat keskittyneet pääasiassa nuorempiin ikäryhmiin. Tämä tutkimus tuottaa uutta tietoa näkö- ja kuulovaikeuksien yleisyydestä nopeasti kasvavassa vanhimmassa ikäryhmässä ja osoittaa, että heillä,joilla on vaikeuksia molemmissa aisteissa, on erityisen suuri riski heikentyneeseen liikkumiskykyyn ja itsearvioituun toimintakykyyn. Lisäksi tutkimus tuottaa tietoa aistivaikeuksien merkityksestä 90 vuotta täyttäneiden elämässä.

Tässä tutkimuksessa itse raportoituja aistivaikeuksia oli lähes puolella vastaajista. Näkövaikeuksia oli noin joka viidennellä ja kuulovaikeuksia joka kuudennella tutkittavalla. Yksittäiset aistivaikeudet eivät juuri eronneet naisten ja miesten välillä, mutta vaikeudet molemmissa aisteissa olivat hieman yleisempiä naisilla (13\% vs. $8 \%$ ). Tässä tutkimuksessa aistivaikeuksia raportoitiin selvästi vähemmän kuin tutkimuksissa, joissa aistivaikeuksia on mitattu objektiivisilla mittareilla (Collerton ym. 2009), mutta tulos vastaa melko hyvin vakavien (Gussekloo ym. 2005) ja itse raportoitujen näkö- ja kuulovaikeuksien yleisyyttä vanhimmassa ikäryhmässä (Cimarolli \& Jopp 2014). Hyvin vanhoja on usein vain vähän väestötutkimuksissa, joissa on tarkasteltu sekä näköettä kuulovaikeuksien yhtäaikaista esiintymistä. Joitain viitteitä on kuitenkin siitä, että hyvin vanhoilla naisilla molempien aistivaikeuk- sien esiintyminen olisi hieman yleisempää kuin miehillä (Schneider ym. 2012).

Tässä tutkimuksessa näkö- ja kuulovaikeudet olivat yhteydessä heikentyneeseen liikkumiskykyyn sekä huonoon ja keskivertoon itsearvioituun toimintakykyyn, ja yhteys oli samankaltainen miehillä ja naisilla. Myös avovastauksissa kerrottiin, kuinka aistivaikeudet aiheuttavat ongelmia fyysisessä toimintakyvyssä ja rajoittavat päivittäisiä toimintoja. Tulos on linjassa aikaisempien tutkimusten kanssa, joissa tutkittavat ovat olleet pääosin nuorempia kuin tässä tutkimuksessa (Crews \& Campbell 2004; Brennan ym. 2005). Brennan ja kumppanit (2006) esittävät kattavassa yhdysvaltalaistutkimuksessa, kuinka näkö- ja kuulovaikeudet ovat hierarkkisesti yhteydessä toimintakyvyn rajoitteisiin. Tässäkin tutkimuksessa hierarkia tuli esiin: näkövaikeuksien yhteys heikentyneeseen itsearvioituun toimintakykyyn ja liikkumiseen oli kuulovaikeuksia vahvempi, ja henkilöillä, joilla oli vaikeuksia molemmissa aisteissa, oli kaikista suurin riski heikentyneeseen toimintakykyyn. Samansuuntainen hierarkkinen yhteys aistivaikeuksien ja toimintakyvyn välillä on havaittu aikaisemmin myös hyvin vanhoilla, mutta tutkimuksen luotettavuutta heikentää sen pieni otos ( $\mathrm{N}=119)$ (Cimarolli \& Jopp 2014).

Mekanismit,jotka yhdistävät heikentyneen kuulon ja heikentyneen toimintakyvyn, voivat liittyä ongelmiin sisäkorvassa, missä tapahtuu sekä tasapainon että äänen aistiminen. Hyvä tasapaino on merkittävä tekijä toimintakyvyn ylläpitämisessä ja päivittäisistä toiminnoista selviämisessä. (Chen ym. 2014.) Näköaisti on puolestaan tärkeä ympäristön hahmottamisen kannalta, ja yhdessä asento- ja liikeaistin kanssa se säätelee tasapainoa. Heikentynyt näkökyky on yhteydessä muun muassa kaatumisriskiin, ja yhdistettynä kuulo- ja tasapainovaikeuksiin se hankaloittaa päivittäisistä toiminnoista selviämistä. (Kulmala ym. 2009.)

Tässä tutkimuksessa erityisesti niillä henkilöillä, joilla oli sekä näkö- että kuulovaikeuksia, oli suurin riski avun tarpeeseen liikkumisessa sekä heikompi itsearvioitu toimintakyky. 
Brennan ja kumppanit (2005) havaitsivat, että henkilöillä, joilla oli vaikeuksia molemmissa aisteissa, oli vaikeuksia selviytyä erityisesti välineellisistä päivittäistoiminnoista (mm. puhelimen käyttö). Myös Davidsonin ja Guthrien (2017) tutkimuksessa 70 prosenttia 65-vuotiaista ja sitä vanhemmista kotihoidon asiakkaista, joilla oli sekä näkö- että kuulovaikeus, koki vaikeuksia välineellisissä toiminnoissa, kun taas lähes puolet koki vaikeuksia päivittäisissä perustoiminnoissa (hygienia, wc-käynnit, syöminen). Lisäksi Viljasen ja kumppaneiden (2014) mukaan sosiaalinen aktiivisuus oli vähäisintä heillä, joilla oli sekä näkö- että kuulovaikeuksia. Rajoittaessaan sosiaalista kanssakäymistä vaikeudet molemmissa aisteissa voivat johtaa eristäytymiseen tai yksinäisyyteen, jotka voivat välillisesti vaikuttaa toimintakyvyn heikkenemiseen.

Muistisairaus, diabetes, masennus ja huimaus selittivät osan aistivaikeuksien ja toimintakyvyn yhteydestä mutta eivät poistaneet sitä. Hyvä kuulo ja etenkin kuullun ymmärtäminen edellyttävät kognitiivista toimintakykyä. Heikentynyt kuulo kuormittaa kognitiivista kapasiteettia, mikä saattaa näkyä heikentyneenä kognitiivisena toimintakykynä sekä tarkkaavaisuuden puutteena (Tun ym. 2009; Maharani ym. 2020), jotka ovat puolestaan yhteydessä heikentyneeseen fyysiseen toimintakykyyn. Toisaalta taas vähentynyt aivojen stimulointi kommunikaation vähentyessä saattaa johtaa kognition heikkenemiseen. Hypoteeseja on esitetty myös siitä, että kognition heikkeneminen voi johtaa aistivaikeuksiin, ja siitä, että sekä kognition heikkeneminen että aistivaikeudet ovat seurausta yleisistä ikääntymismuutoksista. (Maharani ym. 2020.) Vaikka aistivaikeuksien ja kognition väliset syy-seuraussuhteet eivät ole tarkkaan tiedossa, aistivaikeudet yhdessä kognitiivisten rajoitteiden kanssa vaikeuttavat arjen toiminnoista selviytymistä ja lisäävät siten avun tarvetta (Whitson ym. 2015) sekä terveyspalvelujen käyttöä (Lugo-Palacios \& Gannon 2017). Henkilöitä, joilla on vaikeuksia aisteissa, voidaan pitää myös virheellisesti kognitioltaan heikentyneinä, kuten vastaajamme kertoi, mikä puolestaan voi johtaa väärinkäsityksiin kommunikaatiossa.

Tutkimuksemme avovastauksissa kerrottiin aistivaikeuksien tuomista haasteista sosiaalisessa kanssakäymisessä. Aikaisemmissa tutkimuksissa vanhainkodin asukaat, joilla oli näkö- ja kuulovaikeuksia, ovat kertoneet ongelmista arkeen osallistumisessa ja omaan henkilökohtaiseen tilaan, kuten omaan hoitoon, vaikuttamisessa (Roets-Merken ym. 2017), vaikeuksista vuorovaikutuksessa ja sosiaalisen eristäytymisen tunteesta (Cook ym. 2006). Myös kotihoidon asiakkailla aistivaikeudet olivat yhteydessä kommunikaatiovaikeuksiin, yksinäisyyteen, toisten ymmärtämiseen ja ymmärretyksi tulemiseen (Davidson \& Guthrie 2017). Aistivaikeuksiin liittyvät sosiaalisen kanssakäymisen ongelmat heijastuvat myös vanhojen ihmisten hoitoon. Esimerkiksi Yamadan ja kumppaneiden (2015) tutkimuksessa aistivaikeudet ja erityisesti vaikeudet molemmissa aisteissa ennustivat 12 kuukauden seurannassa hoitajien arvioimia käyttäytymiseen liittyviä oireita, kuten vaeltelua, sosiaalisesti epäsopivaa käyttäytymistä ja hoidon vastustamista vanhainkotien asukkailla.

Vastaajat kuvasivat myös, kuinka elämä aistivaikeuksien kanssa oli sujuvaa, ja kertoivat käytössään olevista keinoista kompensoida aistivaikeuksia. Näihin kuuluivat niin erilaiset apuvälineet kuin mukautuminen tilanteeseen ja aikaisempien tottumusten tai harrastusten korvaaminen toisilla. Huonoa kuuloa saatettiin kompensoida toimivalla näköaistilla. Toisen aistin käyttäminen kompensoinnissa selittää todennäköisesti osaltaan huonompaa toimintakykyä heillä, joilla on ongelmia molemmissa aisteissa. Yksi vastaaja kertoi television kuuntelua helpottavasta digitaalisesta kuulokojeesta ja muutama vastaaja valaistuksen lisäämisestä. Muita niin sanottuja ikäteknologian keinoja, kuten asunnon muokkaamista liikkumisen helpottamiseksi (Pinto ym. 1997; Leikas 2014) tai älylaitteiden käyttöä, eivät vastaajat kuvanneet (Leikas 2014). Asunnon ja asuinympäris- 
tön hyvällä suunnittelulla ja muutostöillä voitaisiin lisätä turvallisuutta ja tukea arkea ja kotona asumista myös ikääntyneillä, joilla on aistivaikeuksia (Verma 2014).

Sosioekonomiset erot terveydessä ja toimintakyvyssä tunnetaan yhä paremmin myös hyvin vanhoilla (Enroth ym. 2013), mutta sosioekonomisen aseman yhteydestä aistivaikeuksiin tutkimustietoa on huomattavasti vähemmän. Maharanin ja kumppaneiden (2020) tutkimuksessa (Health and Retirement Study) lyhyempi koulutus oli yhteydessä kuulo- ja näkövaikeuksiin sekä vaikeuksiin molemmissa aisteissa, ja Cruickshanks ja kumppanit (2010) havaitsivat, että iäkkäillä miehillä lyhyempi koulutus oli yhteydessä kuulovaikeuksiin. Dawesin ja kumppaneiden (2014) tutkimus puolestaan osoitti, että keski-ikäisillä näkövaikeudet olivat yleisempiä heikommassa sosioekonomisessa asemassa olevilla. Tässä tutkimuksessa kuulo- tai näkövaikeuksia raportoivat useammin vähemmän koulutut naiset, mutta miehillä koulutusryhmien välillä erot eivät olleet tilastollisesti merkitseviä. Molempia aistivaikeuksia esiintyi hieman enemmän kansakoulun käyneillä miehillä ja naisilla verrattuna korkeammin kouluttautuneisiin, mutta erot ryhmien välillä olivat pieniä. Regressioanalyysissa koulutus ei vaikuttanut aistivaikeuksien ja toimintakyvyn yhteyteen, eli aistivaikeuksien ja toimintakyvyn välillä näyttäisi olevan koulutuksesta riippumaton yhteys.

\section{Tutkimuksen vahvuudet ja rajoitteet}

Tutkimustulokset perustuvat Tervaskannot 90+ -tutkimuksen uusimpaan vuoden 2018 kyselyaineistoon, jossa vastausprosentti oli 77. Korkean vastausprosentin lisäksi tutkimuksen vahvuutena on suuri kyselyaineisto $(\mathrm{N}=1878)$, jolla kerättiin tietoa sekä kotona asuvilta että ympärivuorokautisessa hoidossa olevilta. Tampereen 90 vuotta täyttänyt väestö vastaa monilta osin koko Suomen vastaavan ikäistä väestöä. Muun muassa sukupuolijakauma (naiset $75 \%$, mie- het $25 \%$ ) ja 90 vuotta täyttäneiden osuus koko väestöstä (1\%) ovat samaa luokkaa. Tutkimuksen tulosten ajatellaan näin ollen olevan yleistettävissä 90 vuotta täyttäneiden ikäryhmään koko väestön tasolla. Tutkimuksen menetelmällisenä vahvuutena on sekä määrällisen että laadullisen aineiston käyttö. Monimenetelmätutkimuksen avulla oli mahdollista tuottaa laaja-alaisempi ymmärrys aistitoimintojen yhteydestä toimintakykyyn ja niiden merkityksestä 90 vuotta täyttäneiden arjessa. Esimerkiksi laadullisella aineistolla havaittuja kompensaatiokeinoja ei olisi ollut mahdollista tarkastella vain määrällisellä aineistolla, ja toisaalta aistivaikeuksien yleisyydestä ja mahdollisista aistivaikeuksien ja toimintakykyvaikeuksien yhteyttä selittävistä tekijöistä ei olisi saatu tietoa vain laadullisella aineistolla.

Tutkimuksessa on myös rajoitteita. Vaikka vastausprosentti oli korkea, 23 prosenttia ei osallistunut tutkimukseen. Kyselytutkimukseen yhdistetyt Tilastokeskuksen kuolintiedot osoittivat, että kolme kuukautta kyselyn suorittamisen jälkeen kuolleisuus oli korkeampaa heillä, jotka eivät olleet vastanneet kyselyyn. Tarkastelu vahvistaa sen, että hyvin vanhoja tutkittaessa kyselyyn vastaajat ovat parempikuntoisia kuin vastaamatta jättäneet. Tämä tarkoittaa, että aistivaikeuksien esiintyvyys on todennäköisesti väestötasolla hieman yleisempää kuin tässä tutkimuksessa on esitetty. Lisäksi kyselyllä kerätyt tiedot aistivaikeuksista olivat itse raportoituja ja sisälsivät mahdollisuuden silmälasien ja kuulolaitteen käyttöön. Itse raportoidut aistivaikeudet perustuvat koettuihin vaikeuksiin, mihin vaikuttavat muun muassa erilaiset odotukset näkö- ja kuuloaistien tasosta. On hyvin todennäköistä, että tutkitussa ikäryhmässä aistivaikeuksia raportoidaan todellista vähemmän, koska niiden ajatellaan olevan osa luonnollista vanhenemisprosessia. Erilaisilla aistitoimintojen mittausmenetelmillä on omat vahvuutensa ja rajoitteensa, ja itse raportoidut aistivaikeudet kuvaavat erityisen hyvin arkielämässä koettuja vaikeuksia, joilla on suuri merkitys muun muassa toimintaky- 
vyn ja kotona asumisen kannalta (Brennan ym. 2006).

Tutkimuksessa oli mukana myös sijaisvastaajia. Aikaisemman tutkimustiedon mukaan sijaisvastaajat arvioivat usein tutkittavan terveyden heikommaksi kuin tutkittava itse (Lum ym. 2005). Itsearvioidussa toimintakyvyssä 9 prosentilla oli puuttuva tieto. Näistä suurin osa selittyi sillä, että kysymyksen subjektiivisen luonteen vuoksi sijaisvastaajia ei pyydetty vastaamaan tähän kysymykseen. Suuri osa oli kuitenkin vastannut kysymykseen, ja huomioimme myös sijaisvastaukset analyysissa. Sensitiivisyysanalyysi, jossa kyselyyn vastaaja vakioitiin (vastasi itse / joku muu vastasi), ei vaikuttanut tuloksiin. Lisäksi erillinen analyysi, jossa tarkasteltiin vain itse tai avun kanssa vastanneita, tuotti saman tuloksen kuin analyysi, jossa olivat mukana myös sijaisvastaajat. Tulokset aistivaikeuksien yhteydestä itsearvioituun toimintakykyyn ja liikkumiskykyyn olivat samassa linjassa,joten sijaisvastaajien käytön ei uskota vaikuttaneen tuloksiin.

Tutkimusta varten avovastauksista koottu laadullinen aineisto on rajallinen eikä välttämättä saavuta kaikkia aiheen kannalta tärkeitä näkökulmia. Aineisto kuvaa todennäköisesti sellaisten henkilöiden arkea, joilla aistivaikeudet häiritsevät päivittäistä elämää. Tehdyt havainnot saavat kuitenkin tukea aikaisemmista tutkimuksista ja ovat linjassa tämän tutkimuksen määrällisen aineiston tulosten kanssa. Yksin laadullinen aineisto ei olisi riittävä, mutta yhdessä määrällisen analyysin kanssa se lisää ymmärrystä niiden yli 90-vuotiaiden arjesta, joilla on aistivaikeuksia.

\section{Johtopäätökset}

Tämä monimenetelmätutkimus tuottaa tietoa aistivaikeuksien yleisyydestä ja niiden yhteydestä toimintakykyyn sekä lisää ymmärrystä aistivaikeuksien merkityksestä nopeasti kasvavan vanhimman ikäryhmän arjessa. Tässä tut- kimuksessa itse raportoituja näkö- tai kuulovaikeuksia oli noin puolella 90 vuotta täyttäneistä. Aistivaikeudet olivat yleisempiä ympärivuorokautisessa hoidossa olevilla, sijaisvastaajia käyttäneillä, kansakoulun käyneillä (naiset) ja heillä, joilla oli usein huimausta, muistisairaus tai masennusta. Näkö- ja kuulovaikeudet olivat erikseen yhteydessä heikentyneeseen liikkumis- ja toimintakykyyn ja hankaloittivat muun muassa yhteydenpitoa ja mielekästä tekemistä. Tulokset osoittivat myös hierarkkisesti voimistuvan yhteyden kuulo-, näkö- ja molempien aistivaikeuksien ja toimintakyvyn välillä. Tutkimuksessa vakioitiin useita aistivaikeuksiin ja toimintakykyyn vaikuttavia tekijöitä, mutta ne eivät selittäneet yhteyttä.

Tässä tutkimuksessa näkö- ja kuulovaikeuksia kartoitettiin kysymällä, onko tutkittavilla aistivaikeuksia silmälasien ja/tai kuulolaitteen käytöstä huolimatta. Koska aistivaikeudet olivat verrattain yleisiä, kyseisten apuvälineiden toimivuuden varmistaminen ja päivittäminen voisi osin helpottaa arjen toiminnoista selviytymistä. Toisaalta, toimintakyvyn heikkeneminen havaitaan usein ensin välineellisissä toiminnoissa (Kingston ym. 2012), ja tarkempi tutkimus aistivaikeuksien yhteydestä yksittäisten toimintojen heikkenemiseen voisi lisätä ymmärrystä erilaisista avuntarpeista. Lisää tietoa tarvitaan myös siitä, millaisia kompensaatiokeinoja tai aistivaikeuksia helpottavia teknologioita yli 90-vuotiailla on käytössä, ja miten niitä tulisi kehittää, että esimerkiksi kotona asumista voitaisiin tukea. Tämä olisi erityisen tärkeää niille henkilöille, joilla molemmat aistit ovat heikentyneet, eikä vaikeutta yhdessä aistissa voi kompensoida toisella.

\section{Yhteydenotto:}

Linda Enroth, TtT, tutkijatohtori

Yhteiskuntatieteiden tiedekunta

(terveystieteet) ja Gerontologian

tutkimuskeskus

Tampereen yliopisto

linda.enroth@tuni.fi 


\section{Kirjallisuus}

Aggarwal N, Bennett D, Bienias J, Mendes de Leon C, Morris MC, Evans D. The prevalence of dizziness and its association with functional disability in a biracial community population.J Gerontol A 2000;55(5):M288-92.

https://doi.org/10.1093/gerona/55.5.M288

Armstrong D, Charlesworth E, Alderson AJ, Elliott DB. Is there a link between dizziness and vision? A systematic review. Ophthalmic Physiol Opt 2016;36(4):477-86. https://doi.org/10.1111/opo.12299

Brennan M, Horowitz A, Su YP. Dual sensory loss and its impact on everyday competence. Gerontologist 2005;45(3):337-46. https://doi.org/10.1093/geront/45.3.337

Brennan M, Su YP, Horowitz A. Longitudinal associations between dual sensory impairment and everyday competence among older adults. J Rehabil Res Dev 2006;43(6):777-92. https://doi.org/10.1682/JRRD.2005.06.0109

Chen DS, Genther DJ, Betz J, Lin FR. Association between hearing impairment and self-reported difficulty in physical functioning. J Am Geriatr Soc 2014;62(5):850-6.

https://doi.org/10.1111/jgs.12800

Cimarolli VR, Jopp DS. Sensory impairments and their associations with functional disability in a sample of the oldest-old. Qual Life Res 2014;23(7):1977-84. https://doi.org/10.1007/s11136-014-0657-0

Collerton J, Davies K, Jagger C, Kingston A, Bond $\mathrm{J}$, Eccles MP ym. Health and disease in 85 year olds: baseline findings from the Newcastle 85+ cohort study. BMJ 2009;339:b4904. https://doi.org/10.1136/bmj.b4904

Cook G, Brown-Wilson C, Forte D. The impact of sensory impairment on social interaction between residents in care homes. Int J. Older People Nurs. 2006;1(4):216-24.

https://doi.org/10.1111/j.17483743.2006.00034.x

Creswell J, Plano Clark VL. Designing and conducting mixed methods research. Third Edition. Los Angeles: Sage, 2018.

Crews JE, Campbell VA. Vision impairment and hearing loss among community-dwelling older Americans: implications for health and function- ing. Am J Public Health 2004;94(5): 823-9.

https://doi.org/10.2105/AJPH.94.5.823

Cruickshanks KJ, Nondahl DM, Tweed TS, Wiley TL, Klein BEK, Klein R ym. Education, occupation, noise exposure history and the $10-y r$ cumulative incidence of hearing impairment in older adults. Hear Res 2010;264(1-2):3-9.

https://doi.org/10.1016/j.heares.2009.10.008

Davidson J, Guthrie D. Older adults with a combination of vision and hearing impairment experience higher rates of cognitive impairment, functional dependence, and worse outcomes across a set of quality indicators. J Aging Health 2017;31(1):85-108.

https://doi.org/10.1177/0898264317723407

Dawes P,Dickinson C, Emsley R, Bishop PN, Cruickshanks KJ, Edmondson-Jones M ym. Vision impairment and dual sensory problems in middle age. Ophthalmic Physiol Opt 2014;34(4):47988. https://doi.org/10.1111/opo.12138

Enroth L, Raitanen J, Hervonen A, Jylhä M. Do socioeconomic health differences persist in nonagenarians? J Gerontol B Psychol Sci Soc Sci 2013;68(5):837-47. https://doi.org/10.1093/geronb/gbt067

Enroth L, Veenstra M, Aartsen M, Kjær AA, Juul Nilsson C, Fors S. Are there educational disparities in health among the oldest old? Evidence from the Nordic countries. Eur J Ageing 2019;16(4):415-24. https://doi.org/10.1007/s10433-019-00517-x

Genther D, Frick K, Chen D, Betz J, Lin F. Association of hearing loss with hospitalization and burden of disease in older adults. J Am Geriatr Soc 2013;309(22):2322-4.

https://doi.org/10.1001/jama.2013.5912

Graydon K, Waterworth C, Miller H, Gunasekera H. Global burden of hearing impairment and ear disease. J Laryngol Otol 2019;133(1):18-25. https://doi.org/10.1017/S0022215118001275

Gussekloo J, de Craen AJ, Oduber C, van Boxtel MP, Westendorp RG. Sensory impairment and cognitive functioning in oldest-old subjects: the Leiden 85+ Study. Am J Geriatr Psychiatry 2005;13(9):781-6. https://doi.org/10.1097/00019442-20050900000006 
Halonen P, Enroth L, Jylhä M, Tiainen K. Pitkäaikaissairaudet ja monisairastavuus hyvin vanhoilla sekä niiden yhteys toimintakykyyn ja itse arvioituun terveyteen - Tervaskannot 90+-tutkimus. Gerontologia 2017;31(4):269-81.

Javitt J,Zhou Z, Willke R. Association between vision loss and higher medical care costs in Medicare beneficiaries. Ophthalmology 2007;114(2):23845.

https://doi.org/10.1016/j.ophtha.2006.07.054

Jylhä M, Enroth L, Luukkaala T. Trends of functioning and health in nonagenarians - the Vitality 90+ Study. In: Robine JM, Jagger C, Crimmins E, ed. Annual review of gerontology and geriatrics. Volume 33. Healthy longevity: a global approach. New York: Springer, 2013:313-32.

Kingston A, Collerton J, Davies K, Bond J, Robinson L, Jagger C. Losing the ability in activities of daily living in the oldest old: a hierarchic disability scale from the Newcastle 85+ study. PLoS One 2012;7(2):e31665. https://doi.org/10.1371/journal.pone.0031665

Kulmala J, Era P, Pärssinen O, Sakari R, Sipilä S, Rantanen T, Heikkinen E. Lowered vision as a risk factor for injurious accidents in older people. Aging Clin Exp Res 2008;20(1):25-30. https://doi.org/10.1007/BF03324744

Kulmala J, Viljanen A, Sipilä S, Pajala S, Pärssinen O, Kauppinen M ym. Poor vision accompanied with other sensory impairments as a predictor of falls in older women. Age Ageing 2009;38(2):162-7. https://doi.org/10.1093/ageing/afn228

Käypä hoito. Diabeettinen retinopatia - diabetekseen liittyvä silmäsairaus. 2017. Internet: https://www.kaypahoito.fi/khp00059 (viitattu 2.5.2020).

Laitinen A, Laatikainen L, Härkänen T, Koskinen S, Reunanen A, Aromaa, A. Prevalence of major eye diseases and causes of visual impairment in the adult Finnish population: a nationwide population-based survey. Acta Ophthalmol 2010;88(4):463-71.

https://doi.org/10.1111/j.17553768.2009.01566.x

Leikas J, toim. Ikäteknologia. Helsinki: Vanhustyön keskusliitto, 2014.

Lopez D, McCaul K, Hankey G, Norman P, Almeida O, Dobson A ym. Falls, injuries from falls, health related quality of life and mortality in older adults with vision and hearing impairment - is there a gender difference? Maturitas 2011;69(4):359-64. https://doi.org/10.1016/j.maturitas.2011.05.006

Lugo-Palacios D, Gannon B. Health care utilisation amongst older adults with sensory and cognitive impairments in Europe. Health Econ Rev 2017;7(44). https://doi.org/10.1186/s13561-017-0183-1

Lum TY, Lin W, Kane RL. Use of proxy respondents and accuracy of minimum data set assessments of activities of daily living.J Gerontol A Biol Sci Med Sci 2005;60(5):654-9. https://doi.org/10.1093/gerona/60.5.654

Maharani A, Dawes P, Nazroo J, Tampubolon G, Pendleton N. Associations between self-reported sensory impairment and risk of cognitive decline and impairment in the Health and Retirement Study Cohort.J Gerontol B 2020;75(6):1230-42. https://doi.org/10.1093/geronb/gbz043

Moreira B de S, Sampaio RF, Furtado SR, Dias RC, Kirkwood RN. The relationship between diabetes mellitus, geriatric syndromes, physical function, and gait: A review of the literature. Curr Diabetes Rev 2016;12(3):240-51. https://doi.org/10.2174/1573399811666150615 142746

Pinto M, Medici de S, Zlotnicki A, Bianchi A, Sant van $C$, Napou C. Reduced visual acuity in elderly people: the role of ergonomics and gerontechnology. Age Ageing 1997;26(5):339-44.

https://doi.org/10.1093/ageing/26.5.339

Roets-Merken L, Zuidema S, Vernooij-Dassen M, Dees M, Hermsen P, Kempen G, Graff M. Problems identified by dual sensory impaired older adults in long-term care when using a self-management program: A qualitative study. PLoS One 2017;12(3):e0173361. https://doi.org/10.1371/journal.pone.0173601

Sandelowski M. Combining qualitative and quantitative sampling, data collection, and analysis techniques in mixed-method studies. Res Nurs Health 2000;23(3):246-55.

https://doi.org/10.1002/1098-

$240 \mathrm{X}(200006) 23: 3<246::$ AID

NUR9>3.0.CO;2-H

Schneider J, Gopinath B, McMahon C, Teber E, Leeder SR, Wang JJ, Mitchell P. Prevalence and 5 -year incidence of dual sensory impairment in an older Australian population. Ann Epidemiol 2012;22(4):295-301. https://doi.org/10.1016/j.annepidem.2012.02.004 
Suomen virallinen tilasto. SVT. Väestöennuste. Helsinki: Tilastokeskus. 2020. Internet: http://www. stat.fi/til/vaenn/index.html (viitattu 7.5.2020).

Tun PA, McCoy S, Wingfield A. Aging, hearing acuity, and the attentional costs of effortful listening. Psychol Aging 2009;24(3):761-6. https://doi.org/10.1037/a0014802

Verma I.Teknologia ikääntyneen itsenäisen asumisen tukena. Teoksessa Leikas J, toim. Ikäteknologia. Helsinki: Vanhustyön keskusliitto, 2014:267-81.

Viljanen A, Törmäkangas T, Vestergaard S, Andersen-Ranberg K. Dual sensory loss and social participation in older Europeans. Eur J Ageing 2014;11(2):155-67. https://doi.org/10.1007/s10433-013-0291-7

Whitson HE, Liu P, Fillenbaum GG, Burchett BM, Cohen HJ. Defining care needs in older adults with a particular set of multiple chronic conditions: coexisting visual, auditory and cognitive impairments.J Patient Cent Res Rev 2015;2(2):103. http://dx.doi.org/10.17294/2330-0698.1111

Yamada Y, Denkinger MD, Onder G, Finne-Soveri $H$, van der Roest $H$, Vlachova M ym. Impact of dual sensory impairment on onset of behavioral symptoms in European nursing homes: results from the services and health for elderly in long-term care study. J Am Med Dir Assoc 2015;16(4):329-33.

https://doi.org/10.1016/j.jamda.2014.11.006

Zhang W, Creswell J. The use of "mixing" procedure of mixed methods in health services research. Med Care 2013;51(8):e51-e57. https://doi.org/10.1097/ MLR.0b013e31824642fd 